University of Nebraska - Lincoln

DigitalCommons@University of Nebraska - Lincoln

Virology Papers

Virology, Nebraska Center for

$1-26-1984$

\title{
Activation of a Translocated Human c-myc Gene by an Enhancer in the Immunoglobulin Heavy-Chain Locus
}

\author{
Adrian C. Hayday \\ King's College School of Medicine and Dentistry, adrian.hayday@kcl.ac.uk \\ Stephen D. Gillies \\ Massachusetts Institute of Technology \\ Haruo Saito \\ University of Tokyo, h-saito@ims.u-tokyo.ac.jp \\ Charles Wood \\ University of Nebraska-Lincoln, cwood1@unl.edu \\ Klas Wiman \\ Karolinska Institutet, Klas.Wiman@ki.se \\ See next page for additional authors
}

Follow this and additional works at: https://digitalcommons.unl.edu/virologypub

Part of the Virology Commons

Hayday, Adrian C.; Gillies, Stephen D.; Saito, Haruo; Wood, Charles; Wiman, Klas; Hayward, William S.; and Tonegawa, Susumu, "Activation of a Translocated Human c-myc Gene by an Enhancer in the Immunoglobulin Heavy-Chain Locus" (1984). Virology Papers. 198.

https://digitalcommons.unl.edu/virologypub/198

This Article is brought to you for free and open access by the Virology, Nebraska Center for at DigitalCommons@University of Nebraska - Lincoln. It has been accepted for inclusion in Virology Papers by an authorized administrator of DigitalCommons@University of Nebraska - Lincoln. 
Authors

Adrian C. Hayday, Stephen D. Gillies, Haruo Saito, Charles Wood, Klas Wiman, William S. Hayward, and Susumu Tonegawa 
Published in Nature 307 (January 26, 1984): 334-340. Copyright 1984, Nature Publishing Group. Used by permission.

\title{
Activation of a Translocated Human c-myc Gene by an Enhancer in the Immunoglobulin Heavy-Chain Locus
}

\author{
Adrian C. Hayday*, Stephen D. Gillies", Haruo Saito", Charles Wood*, \\ Klas Wiman ${ }^{\dagger}$, William S. Hayward ${ }^{\dagger} \&$ Susumu Tonegawa*
}

\footnotetext{
"Center for Cancer Research and Department of Biology, Massachusetts Institute of Technology, Cambridge, Massachusetts, USA; ${ }^{\dagger}$ Memorial Sloan-Kettering Cancer Center, New York, New York, USA

A tissue-specific transcriptional enhancer element that is associated with the human immunoglobulin heavy-chain locus is defined. In a non-Hodgkin's lymphoma that contains a translocated c-myc gene this enhancer is retained on the $14 \mathrm{q}^{+}$chromosome and occurs within sequences shown to activate previously cryptic promoters of the c-myc gene.
}

\begin{abstract}
A functional immunoglobulin gene is generated somatically during the differentiation of B lymphocytes by a set of developmentally regulated gene rearrangements ${ }^{1}$, The major function of these rearrangements is to generate a diverse set of complete immunoglobulin genes from a limited number of inherited gene segments.

Another important role of these rearrangements has recently been identified at least for the mouse immunoglobulin heavy-chain genes $^{2-4}$. In an individual B lymphocyte and its progenies, only one of a few hundred copies of the variable $(V)$ gene segments is expressed. This activation of a specific $V$ gene segment results from its direct rearrangement into the vicinity of a transcriptional enhancer element that is located upstream of the constant $(C)$ region gene segments, between the joining $(J)$ segments and the switch $(S)$ region. Interestingly, the immunoglobulin gene-associated enhancer functions in a tissuespecific manner, suggesting a more general involvement of cellular .enhancer elements in tissue-specific expression of eukaryotic genes during cell differentiation.

Another biological process in which gene rearrangements and enhancer elements may play a critical, albeit adventitious, role is tumorigenesis. A model supporting this notion comes from the studies on the chicken leukaemogenesis induced by the non-acute avian leukosis virus (ALV). By integrating close to the cellular oncogene, c-myc, the ALV provirus via its transcriptional promoter or enhancer element can lead to increased levels of c-myc transcription ${ }^{5,6}$. It has
\end{abstract}

recently been shown that the c-myc gene is translocated into an immunoglobulin locus in certain lymphoid neoplasms of both mice and men $^{7-12}$. Thus, murine $c-m y c$ gene is recombined into the immunoglobulin heavy-chain locus in BALBIc plasmacytomas characterized by $\mathrm{t}(12: 15)$ translocations $\mathrm{s}^{7,9-11}$. Likewise,in a majority of the many Burkitt's lymphomas or non-Hodgkin's lymphomas characterized by $\mathrm{t}(8: 14)$ (q24; q32) translocations, the c-myc gene is recombined into the immunoglobulin heavy-chain locus ${ }^{8,11,12}$. It has generally been considered that in these and other neoplasms where nonrandom chromosomal translocations have been observed, c-onc genes are activated by the translocations ${ }^{13-15}$.

To understand the relationship between the translocation and activation of a c-myc gene we have been analysing the structure and expression of normal and translocated human c-myc genes. The results presented here demonstrate that the human immunoglobulin heavy-chain locus carries a transcriptional enhancer element analogous to its mouse counterpart, and that this enhancer element may be playing a direct part in the activation of the translocated c-myc gene in some lymphoid neoplasms.

\section{c-myc translocation in Manca cells}

The non-Hodgkin's lymphoma, Manca ${ }^{16}$, shows a chromosome translocation $(\mathrm{t}(8: 14)$ (q24; q32) that is characteristic of many Burkitt's lymphomas ${ }^{14,15}$. In situ hybridization of a v-myc probe ${ }^{17}$ to Manca 
Figure 1, A comparison of the human c-myc gene and the $C_{\mu}$ region of the human immunoglobulin heavychain locus to the $\mathrm{C}_{\mu}$-c-myc joining region of the 14:8 translocated chromosome from Manca cells. Exons are shown as solid boxes; chromosome 14 sequences as a double line; and chromosome 8 sequences as a single line. $\mathrm{R}$ indicates the site of recombination between the two chromosomes. E is a transcriptional enhancer element, which was previously identified for the mouse immunoglobulin heavy-chain locus ${ }^{2-4}$ and the identification of the human equivalent is reported here. $S_{\mu^{\prime}} C_{\mu}$ switch sequences; $J_{\mu^{\prime}}$ joining segments. The $J_{u}$ segments are defined on the basis of data presented in reference 40, and our own sequencing $^{41}$. The horizontal arrows indicate

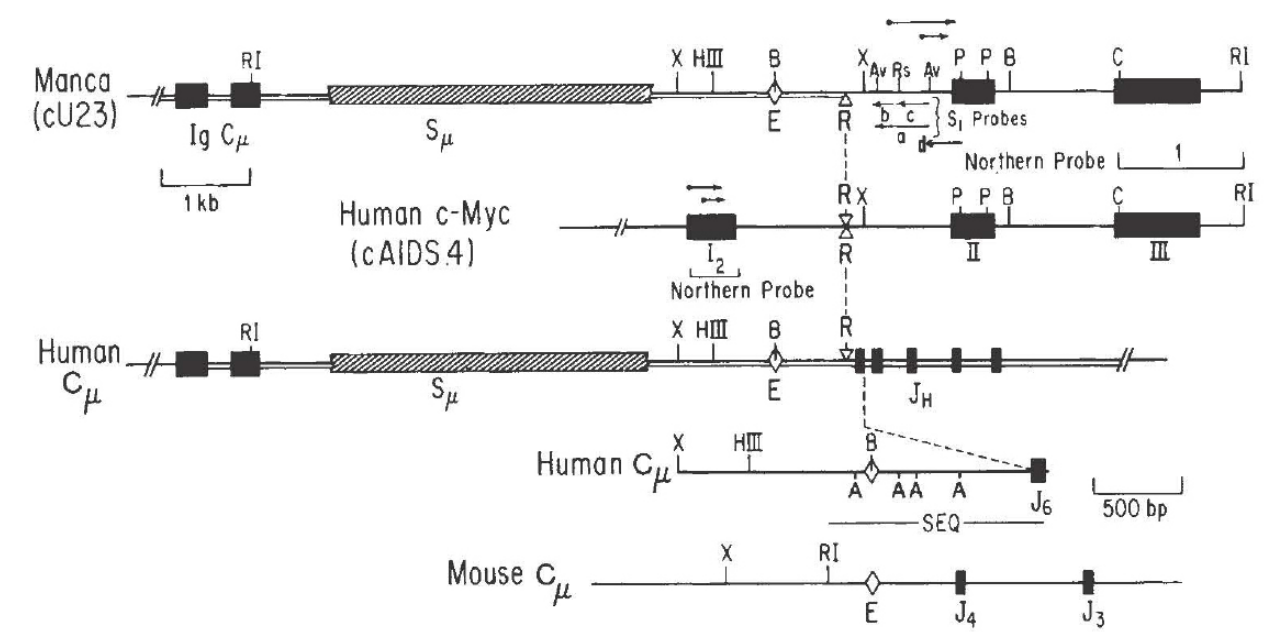

the initiation sites and directions of transcription. Restriction sites: RI, EcoRI; X, XbaI; H, HindIII; Av, AvaI; Rs, RsaI; P, PstI; B, BglII; C, ClaI; A, AluI (the complete map is only shown for the first three of these). 1 and 2 delineate the extent of the probes used in the Northern blot experiments. The cloning of the recombination region of the translocated chromosome into cosmid pTCF $^{19}$ will be described elsewhere (K.W. et al., manuscript in preparation). The unrearranged c-myc gene was also cloned into a cosmid. Colonies were screened with the Northern probe 1 . The definition of the c-myc gene will be described ${ }^{22}$. chromosomes indicates that the human c-myc locus is on that portion of chromosome $8^{12,18}$ that is translocated (data not shown).

From a cosmid library ${ }^{19}$ of Manca DNA a clone, cU23 was isolated that hybridized both to $\mathrm{v}-m y c$ and to $\mathrm{pH} 18-\mathrm{C} 1-10$, a plasmid containing the immunoglobulin heavy-chain $C$ gene and sequences immediately $5^{\prime}$ to it ${ }^{20}$. Southern blot analysis ${ }^{21}$ of Manca DNA indicated that the linkage of $\mathrm{c}-m y c$ and immunoglobulin heavy-chain gene sequences detected in cU23 had occurred in the human cells, and not upon cloning (data not shown). A detailed map of clone cU23 in the region of c-myc- $C_{\mu}$ linkage was derived by restriction analysis and DNA sequencing (K. W. et al., manuscript in preparation), and was compared with maps of human germ-line $C_{\mu}$ and c-myc genes, contained on plasmid pH18-C1-10 and cosmid cAIDS4 respectively (Figure 1). The latter clone was described previously ${ }^{22}$. It can be deduced that in Manca DNA, the human c-myc gene is fused headto-head with the $C_{\mu}$ gene, about 6.5 kilobases $(\mathrm{kb}) 5^{\prime}$ to the first $C_{\mu}$ exon. The junction on chromosome 14 lies between $S_{\mu}$ and $J_{\mathrm{H}} 6$, at a point that is not normally used for the productive rearrangement of an immunoglobulin heavychain gene. The junction on chromosome 8 occurs between exons I and II of the c-myc gene. As a result, the Manca DNA cloned in cU23 contains neither exon I nor the normal transcriptional start sites ${ }^{22}$ of the human c- $m y c$ gene. Instead, c- $m y c$ exons II and III are fused to $C_{\mu}$ sequences that include a stretch of DNA between $S_{\mu}$ and $J_{\mathrm{H}}$ that is in an analogous location to sequences in the mouse genome shown to have tissue-specific transcriptional enhancing activity ${ }^{2-4}$ (region ' $E^{\prime}$ in Figure 1). The translation of transcripts of the human c-myc gene begins within exon II, at an initiation AUG codon that is retained, and presumably used, in transcripts of the translocated c-myc gene in Manca cells.

\section{Multiple transcription initiation sites}

Northern blot analysis of RNA from Manca cells indicates a high level of c-myc transcription (Figure 2A). It is clear that there are multiple transcripts hybridizing to the c-myc Northern probe 1 (see Figure 1). The level of c-myc transcription in Manca cells is the highest that we have detected in any cell line (which include other Burkitt's lymphomas, and Epstein-Barr virusimmortalized Iymphoblastoid cells) except the promyclocytic leukaemia cell line HL60 (data not shown). The relevance of this comparison is unclear, however, as all these cells are growth transformed. An alternative approach is to compare the level of transcription of the rearranged c-myc gene in
Manca cells with that of the unrearranged allele; with a probe specific for exon I no transcription of the unrearranged c-myc gene can be detected in Manca cells (K.W. et al., manuscript in preparation). Therefore, the high c-myc level of transcription in Manca cells all derives from the translocated allele.

The initiation points of c-myc transcripts in Manca cells were mapped by $S_{1}$ nuclease protection experiments ${ }^{23,24}$. using the probes shown at the bottom of Figure 2. The major initiation site (site 1; see Figure 2) for c-myc transcripts occurs about 636 base pairs (bp) upstream of c-myc exon II, within what would ordinarily be intron I of the c-myc gene. The nucleotide numbering system used to denote the initiation points is that of Colby et al. ${ }^{25}$, whose sequence begins within intron I of the human c-myc gene such that nucleotide 1,000 defines the start of exon II. Transcripts initiating at site I (nucleotide 364) form $S_{1}$-resistant hybrids with probes $b$ and a of 66 base pairs (bp) and 359 bp respectively (Figure 2B, C). Downstream of site I, at nucleotide 378 , is a weaker initiation point, Ia (Figure 2B, C). As has been previously noted ${ }^{25}$, upstream of initiation sites I and Ia are sequences related to the consensus TATA box ${ }^{26,27}$ commonly found $5^{\prime}$ of genes transcribed by RNA polymerase II (see Figure 3). Initiating at around nucleotide 873 are further transcripts, which form $\mathrm{S}_{1}$ nuclease-resistant hybrids of length $192 \mathrm{bp}$ with probe d (data not shown), and 28 bp upstream of this site occurs the sequence TTTATT (Figure 3). In addition to these initiation sites, an $\mathrm{S}_{1}$ sensitive site $(X)$ in hybrids between Manca RNA and either probe a or c is detected at around nucleotide 520. However, the assignment of an initiation site to this position is uncertain, an $\mathrm{S}_{1}$-sensitive site also being apparent at this position in hybrids between probes a or $\mathrm{c}$ and yeast RNA on long exposures.

If transcripts initiating at these sites were to have no functional splice sites $5^{\prime}$ of the junction between exon II and the following intron, then the processed RNAs would range in size from 1,660 to 2,450 nucleotides (not including the poly(A) tail ${ }^{28}$ ). That this is the case is suggested by cDNA cloning, which has revealed a contiguous transcript extending upstream from exon II at least as far as position 660. Beyond this point the $S_{1}$ nuclease-sensitive sites have been confirmed as initiation (as opposed to splice) sites by primer extension analyses. For example, reverse transcripts of Manca cell RNA using the primer shown in Figure 2B extend as far as nucleotide 364. Further primer extensions (for example using $S_{1}$ probe $b$ ) indicate no initiation sites upstream of those characterized here (data not shown). 


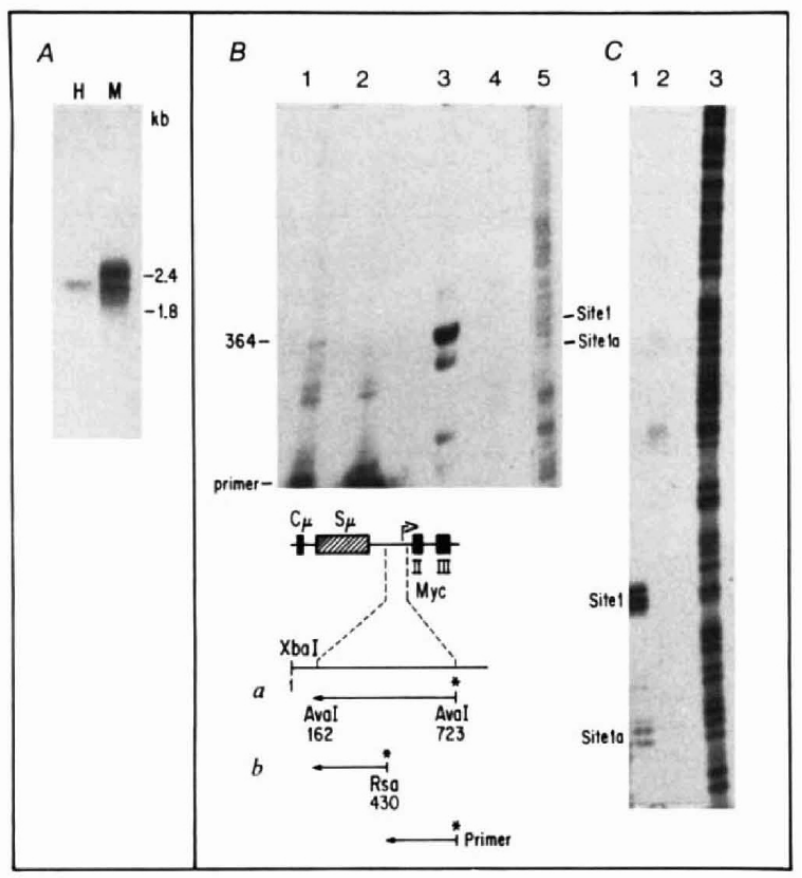

Transcriptional enhancer element

We have previously shown that sequences derived from the $J_{\mathrm{H}}-C_{\mu}$ region of the mouse immunoglobulin heavy-chain locus contain a DNA element that enhances the transcription of the associated gene in a manner largely independent of both position and orientation ${ }^{2}$. The translocation of the c-myc gene in Manca cell DNA just $300 \mathrm{bp}$ downstream of the human $J_{\mathrm{H}}$ cluster (Figure 1) suggested that the high level of c-myc transcription in Manca cells (Figure 2A) might be due to a human enhancer element located in an analogous region to that in the mouse ('E' in Figure 1).

To test this hypothesis, we first attempted to identify the putative human enhancer element. For this purpose, the 2.2 kilobase (kb) XbaI fragment (see Figure 1) containing most of the sequence between the $J_{\mathrm{H}}$ cluster and $S_{\mu^{\prime}}$ plus about $330 \mathrm{bp}$ derived from the $5^{\prime}$ flanking region of the translocated, truncated c-myc gene, was inserted into the EcoRI site of plasmid pSER ${ }^{2}$. This plasmid was derived from pSV2.gpt ${ }^{29}$ (which contains the mycophenolic acid-resistance conferring gene Ecogpt) by deletion from the latter of the SV40 enhancer sequences. As a result, pSER transforms cells to mycophenolic acid resistance (gpt ${ }^{+}$phenotype) at a much lower frequency than does pSV2.gpt (see Table 1). The original level of transformation can be restored by the insertion into the EcoRI site of pSER of the mouse immunoglobulin heavy-chain locus enhancer element ${ }^{2}$. As shown in Table 1, the insertion in either orientation of the human XbaI fragment into the EcoRI site of pSER (2.3 kb upstream of the Ecogpt gene) restored the gpt ${ }^{+}$transformation efficiency to a level even exceeding (by about eightfold) that of pSV2 gpt. The transformation efficiency of pSV2 gpt was itself increased 5-10-fold by insertion of the XbaI into its EcoRI site. Other fragments of mouse and human immunoglobulin heavy-chain loci DNA had no significant effects on transformation frequencies when inserted into pSER of pSV2.gpt. Also, like its murine counterpart the effect of the $\mathrm{X} b a \mathrm{I}$ fragment was tissue-specific: with rodent fibroblasts the transformation efficiencies of pSERXa and pSERXb were over 100 times lower that of pSV2.gpt. In a further experiment the $2.2 \mathrm{~kb}$ XbaI fragment was dissected by cleavage with $A l u \mathrm{I}$, and some of the resulting fragments also tested in the pSER assay. Most, if not all the enhancing activity could be attributed to the $279 \mathrm{bp}$ fragment, Alua (delineated by the two AluI sites flanking the BglI site shown in the expanded map of the human $C_{\mu}$ gene in Figure 1).
Figure 2, A, Northern blot analysis ${ }^{42}$ using the probe 1 shown in Figure 1 of mRNA from: lane $\mathrm{H}$, HeLa cells $(1 \mu \mathrm{g})$; lane $\mathrm{M}$, Manca cells $(0.3 \mu \mathrm{g})$. B, Lanes 1 and 2 show a primer extension analysis ${ }^{43}$, and lanes 3 and 4 an $S_{1}$ nuclease mapping analysis ${ }^{23,24}$ of: lanes 1 and 3, Manca cell mRNA; lanes 2 and 4, yeast mRNA. The probes used are ' $a$ ' and 'primer' shown in the diagram below the photograph of the blot, and were strand separated and end labelled ${ }^{41}$ before hybridization. The nucleotide numbering system derives from reference 25 , and starts (nucleotide 1) at the XbaI site in intron I of the human c-myc gene. Sites 1 and $1 \mathrm{a}$ are referred to in the text; site 1 centers on nucleotide 364 , and the mark indicating this position on the right of the figure shows the correspondence between the primer extension and $\mathrm{S}_{1}$ signals in lanes 1 and 3 . Lane 5 is a pyrimidine analysis ${ }^{41}$ of the sense strand of the probes, from which the nucleotide positions of the DNA-RNA discontinuity could be determined (see Figure 3). C, S, nuclease analysis using the probe ' $b$ ' shownin the diagram below B of mRNA from: lane 1, Manca cells; lane 2, yeast cells. Lane 3 is the same type of reaction as shown in lane 5 of $B$, but using probe $b$.

Methods: The $S_{1}$ nuclease reactions contained either 100 ng Manca cell mRNA plus $20 \mu \mathrm{g}$ yeast RNA, or only the yeast RNA. For the $S_{1}$ analysis $5 \times 104$ c.p.m. of probe was used per reaction, and for the primer extension analysis $2 \times 104$ c.p.m.of probe was used per reaction. The probes were annealed to the RNA at $53^{\circ} \mathrm{C}$ for $4 \mathrm{~h}$ (except in the case of probe b, which was annealed at $30^{\circ} \mathrm{C}$ for 12-16 h). $\mathrm{S}_{1}$ reactions were performed at $15^{\circ} \mathrm{C}$ for $3 \mathrm{~h}$, and primer extension reactions at $41^{\circ} \mathrm{C}$ for $45 \mathrm{~min}$. A $6 \%$ acrylamide gel was used for $\mathrm{B}$, and run for $7 \mathrm{~h}$, and an $8 \%$ gel run for $3 \mathrm{~h}$ for $\mathrm{C}$.

These transformation experiments strongly suggest that the 2.2 $\mathrm{kb}$ human $\mathrm{XbaI}$ fragment contains a tissue-specific transcriptional enhancer element. To demonstrate this point more directly we examined the effect of this DNA fragment on the transcription of a mouse immunoglobulin $\gamma 2 \mathrm{~b}$ gene. The plasmid pSV $\cdot \gamma 2 \mathrm{~b} \Delta \mathrm{x}_{2 / 4}$ contains a functionally rearranged mouse $\gamma 2 \mathrm{~b}$ gene from which most of the sequences (including the enhancer element) between $V$ - D-J and $C$ exons have been deleted ${ }^{2}$. The plasmid also contains the selectable Ecogpt gene. J558L cells transformed to mycophenolic acid resistance by pSV . $\gamma 2 \mathrm{~b} \Delta \mathrm{X}_{2 / 4}$ express almost no $\gamma 2 \mathrm{~b}$ heavy-chain $\mathrm{RNA}^{2}$. A high level of $\gamma 2 \mathrm{~b}$ expression can be restored by re-insertion (either upstream or downstream of the $V-D-J$ promoter) into plasmid pSV $\cdot \gamma 2 \mathrm{~b} \Delta \mathrm{X}_{2 / 4}$ of the mouse enhancer ${ }^{2}$, and similarly by insertion of the human $\mathrm{XbaI}$ fragment (Figure 4). In this experiment, pools of cells transformed to a g $\mathrm{pt}^{+}$phenotype by $\mathrm{pSV} \cdot \gamma 2 \mathrm{~b} \Delta \mathrm{X}_{2 / 4}$ and its derivatives were assayed for $\gamma 2 \mathrm{~b}$ gene expression by $S_{1}$ nuclease protection. The mouse enhancer was equally effective whether inserted upstream or downstream of the $\gamma 2 \mathrm{~b} V$ - D-J promoter. By contrast the level of the $\gamma 2 \mathrm{~b}$ gene transcription attained by the human enhancer was somewhat variable depending on its position, the highest level of expression being obtained when the enhancer was inserted upstream of the promoter in the opposite orientation to the direction of transcription (Figure 4). Interestingly, the relative orientations of enhancer and promoter in this case are equivalent to those of the enhancer and the altered c-myc promoters in Manca cell DNA (see Figure 1).

The nucleotide sequence of a portion of the $J_{\mathrm{H}}-C_{\mu}$ region of the human germ-line clone $\mathrm{pH} 18$-CL-10 was determined and compared with that of the corresponding region of mouse DNA (Figure 5), which contains the enhancer core sequences ${ }^{30}$ which are common to enhancers so far defined. Core-like sequences are present in the human DNA: there is a $67 \%$ matching between the $140 \mathrm{bp}$ of mouse DNA that contains most, if not all, of the murine enhancing activity and the corresponding human sequence. The similarity between the mouse and human sequences throughout the region shown in Figure 5 is sufficiently strong to allow a unique alignment, with several insertions and deletions.

\section{Activation of c-myc transcription}

To begin to investigate whether the high level of c-myc transcription in Manca cells was due to proximity to the immunoglobulin heavy- 

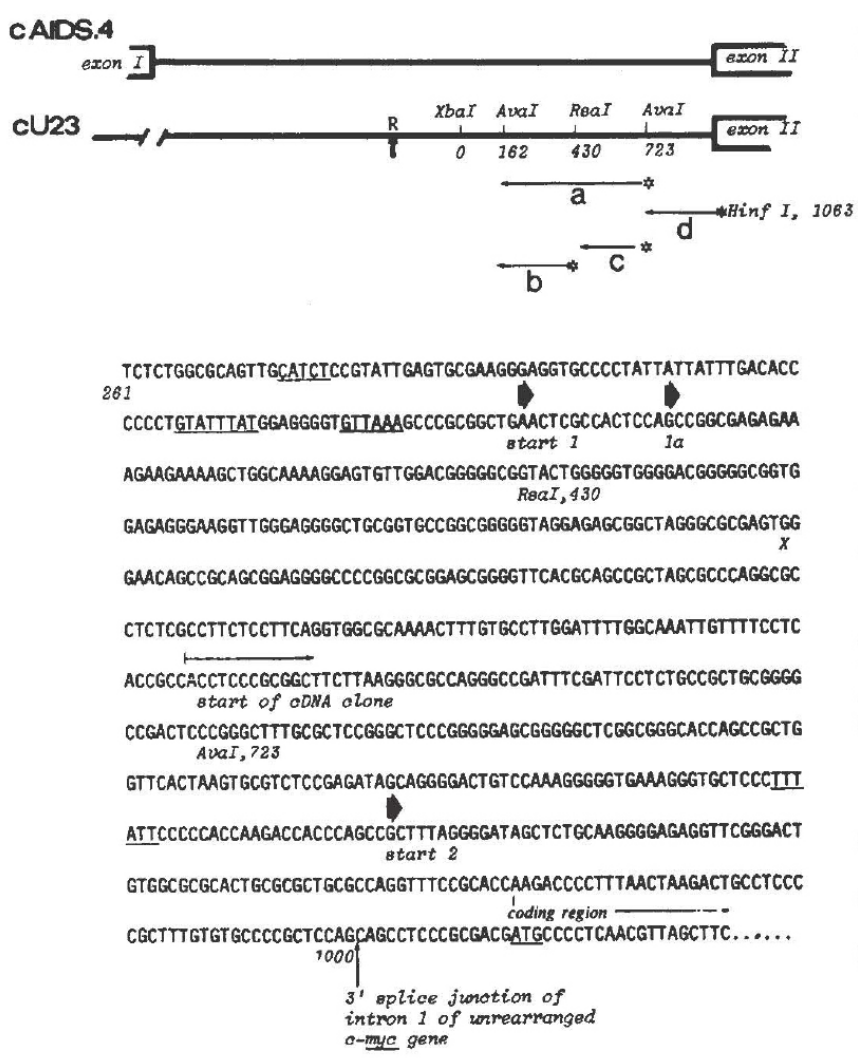

Figure 3, Shows the nucleotide sequence from intron I of the germline c-myc gene that contains the initiation sites of the transcripts of the translocated c-myc gene. The recombination site of the translocated Manca chromosome is 336 nucleotides $5^{\prime}$ of the start of the sequence shown. Exon II of the germline c-myc gene starts at nucleotide 1,000 . The transcription initiation sites $(1$, 1a and 2), as deduced by $S_{1}$ and primer extension analyses, are marked by the thick arrows. The probes used in these analyses ( $\mathrm{a}-\mathrm{d}$, $\mathrm{a}$ and $\mathrm{b}$ being those used in Figure 2) are shown near the top of the figure. The asterisks mark the ${ }^{32} \mathrm{P}$-labelled ends of the probes. Underlined sequences are similar to those commonly found $5^{\prime}$ of RNA polymerase II-transcribed genes ${ }^{27}$. The initiator ATG codon of the protein encoded by c-myc is also underlined. $\mathrm{X}$ is an $\mathrm{S}_{1}$-sensitive site, and $\mathrm{R}$ the recombination site. The sequence data derive from reference 25 plus our own data in the regions of designated promoters.

chain locus enhancer, the transcription of the translocated c-myc gene was studied in a murine mycloma cell line, J558L. The mycloma cells were transformed by spheroplast fusion with either of two plasmids, pSV.26 or pSV2. $\triangle 4$. Plasmid pSV2.26 contains the $11.7 \mathrm{~kb} E c o R I$ fragment from cU23 (containing the translocated c-myc gene plus about $8 \mathrm{~kb}$ of $5^{\prime}$ flanking sequences which include the immunoglobulin heavy-chain locus enhancer, see Figure 1) the translocated c-myc gene cloned into the EcoRI site of pSV2gpt. Plasmid pSV2 $\Delta 4$ contains a $9.5 \mathrm{~kb}$ EcoRI fragment (derived from the $11.7 \mathrm{~kb}$ EcoRI fragment of cU23 by deletion of the central $2.2 \mathrm{~kb} X b a \mathrm{I}$ fragment) cloned into the EcoRI site of pSV2.gpt. Plasmid pSV2 $\triangle 4$ thus lacks the sequences identified above as having transcriptional enhancing activity.

After transforming with these plasmids, $\mathrm{gpt}^{+}$transformants of J558L cells were isolated and assessed for the presence of exogenous DNA. Clones 26.1-26.9 were nine cloned isolates of cells transformed by pSV2.26; $\Delta 4.2$ is a cell line developed after transformation with pSV2. $\Delta 4 ; \Delta 4.1$ is a pool of several colonies transformed by pSV2. $\Delta 4$. Most cells transformed by pSV2.26 have acquired only single or a few copies of the exogenous DNA, and in most of these cases the plasmids
Frequency of transformation to $\mathrm{gpt}^{+}$
phenotype

Plasmid J558 L cells $^{*} \quad$ rat-2 cells $^{\dagger}$

pSV2.gpt $1 \times 10^{-4} \quad 5 \times 10^{-3}$

pSV2.gpt.Xa $a^{\ddagger} \quad 6 \times 10^{-4} \quad$ ND

PSER $5 \times 10^{-6} \quad$ ND

$\begin{array}{lll}\text { pSER.Xa } & 8 \times 10^{-4} & 1 \times 10^{-5}\end{array}$

$\begin{array}{lll}\mathrm{PSERXb} & 8 \times 10^{-4} & 1 \times 10^{-5}\end{array}$

$\begin{array}{lll}\text { PSER.Ra } & 8 \times 10^{-6} & \text { ND } \\ \text { pSER } & 8 \times 10^{-4} & \text { ND }\end{array}$

pSERAlu $\mathrm{z} \| \quad 5 \times 10^{-6} \quad$ ND

Escherichia coli cells containing the above-mentioned plasmids were converted to spheroplasts ${ }^{39}$, and fused ${ }^{2}$ to recipient cells $\left(10^{10}\right.$ spheroplasts per $2 \mathrm{x}$ $10^{6}$ cells), after which the cells were plated at $5 \times 10^{3}$ (J558L) cells per well or 1 $\times 10^{5}$ (rat-2) cells per culture dish. The selective medium, which contained xanthine $\left(250 \mu \mathrm{g} \mathrm{ml}^{-1}\right)$, hypoxanthine $\left(15 \mathrm{\mu g} \mathrm{ml}^{-1}\right)$ and mycophenolic acid $(6.5 \mu \mathrm{g}$ $\mathrm{ml}^{-1}$ ), was added $48 \mathrm{~h}$ after fusion, and colonies were counted after 14 days. The experiments were routinely repeated three times. ND, not done.

"A mouse plasmacytoma cell line.

${ }^{\dagger}$ A rodent fibroblast cell line.

${ }^{\ddagger} \mathrm{Xa} / \mathrm{Xb}$ plasmids contain an insertion in either orientation ( $\mathrm{a}$ or $\mathrm{b}$ ) of the 2.2 $\mathrm{kb}$ XbaI fragment from cU23.

${ }^{\S}$ pSER.Ra contains an insertion of a $4 \mathrm{~kb}$ EcoRI fragment from the mouse immunoglobulin heavy-chain $C_{a}$ gene. $\|$ Alu.a/Alu.z plasmids contain an insertion of either of two AluI fragments ( $a$ and $z$ ) derived from the $2.2 \mathrm{~kb}$ XbaI fragment.

integration has occurred within the $11.7 \mathrm{~kb}$ EcoRI fragment, so that EcoRI fragments smaller than $11.7 \mathrm{~kb}$ are detected with the c-myc probe $^{31}$. Analysis with enzymes that cut within this fragment, however, indicate that in at least four out of nine cases (clones 26.1. 26.2, 26.4 and 26.7) contiguous DNA sequences that extend from the enhancer through the transcriptional initiation sites mapped above, and into the truncated c-myc gene, are intact (Figure 6).

By contrast, the cells transformed in identical conditions by pSV2. $\Delta 4$, contain multiple, tandem copies of the exogenous DNA, and in each case the c-myc transcription unit and upstream sequences are intact. This difference in copy number of transforming DNA in cells selected for gpt $^{+}$phenotype may be due to a positive effect (from over $7 \mathrm{~kb}$ away) of the enhancer on Ecogpt transcription: in the absence of the enhancer, high levels of Ecogpt transcription may only be obtained from an increased copy number. Consistent with this, the transformation frequency of J558L cells by pSV2 $\Delta 4$ is 5-10fold lower than the frequency of transformation by pSV2.26 (data not shown). The difference in copy number may also result from a deleterious effect of excess c-myc gene product on J558 cells, which already contain an actively transcribed translocated mouse c-myc gene $^{32}$. If such an effect exists, and if the immunoglobulin heavychain locus enhancer does activate Manca cell c-myc transcription, then there may be a selective advantage to cells transformed with pSV2.26 that retain only one or even no intact copies of the Manca cell c-myc gene.

Both total and poly $(\mathrm{A})^{+}$RNA were isolated from groups of transformants, and were analysed by Northern transfer and hybridization to probe 1 (see Figure 1). Although transformants receiving pSV2. 4 contained multiple intact copies of the transfected c-myc gene, none of them showed evidence for much c-myc transcription over and above the level of the mouse c-myc transcription endogenous to J558L cells (data not shown). By contrast several lines of cells transformed by pSV2.26 showed strongly hybridizing c-myc transcripts (data not shown).

Because of the variability in retention of c-myc DNA sequences, and the cross-reactivity of the Northern probe with the mouse c-myc transcripts in J558L cells, a quantitative comparison of human trans- 
located c-myc gene transcription was better made by $\mathrm{S}_{1}$ nuclease mapping. The $S_{1}$ probe a (Figure 3 ), which detects the major initiation site, was protected to a similar quantitative degree by Manca cell RNA and by RNA of several lines transformed by pSV2.26 (for example, lines 26.1, 26.4 and 26.7, see Figure 7). That RNA in these cell lines is qualitatively the same as in Manca cells was further indicated by use of $S_{1}$ probe $b$. Use of either probe shows almost no protection by RNA of cell lines $\Delta 4.1$ or $\Delta 4.2$ (see Figure 7) even though these cells contain multiple intact copies of the transforming DNA
(Figure 6). It cannot be argued that in either of these cases the transforming DNA has become sequestered in a transcriptionally inactive area, since continual selection for Ecogpt gene activity is made. In addition, several isolates of both total and poly(A) ${ }^{+}$RNA from these cells gave the same result, and these RNAs were positive in an $\mathrm{S}_{1}$ nuclease protection assay of Ecogpt transcripts (data not shown). It appears then, that the activity of the major transcriptional initiation site for translocated c-myc gene transcription is severely reduced by deletion of sequences 360 bp upstream of it. Deletions at this dis-

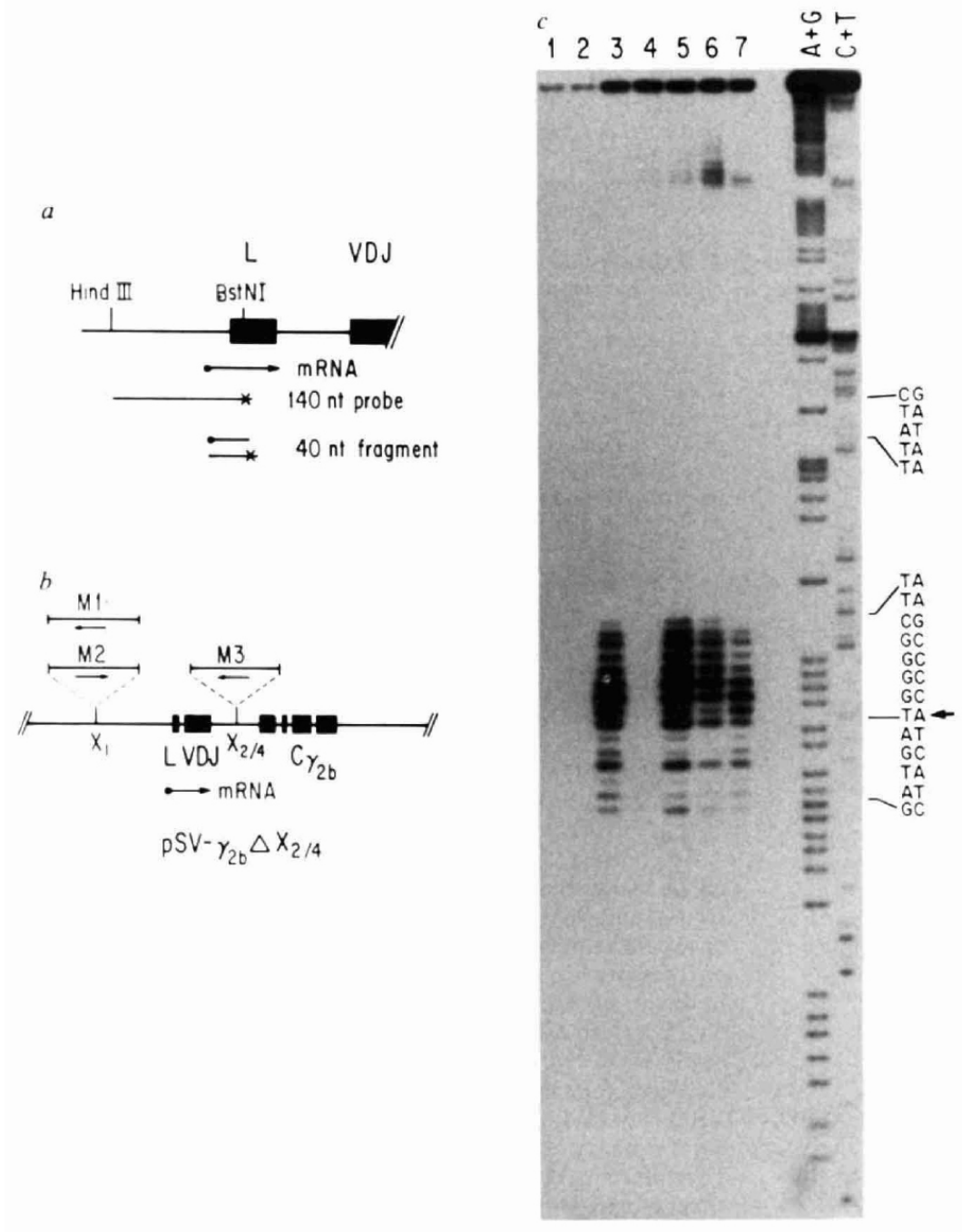

Figure 4, a, Strategy of the $S_{1}$ nuclease mapping experiment shown in c. The probe is an end-labelled HindIII-Bst NI fragment, which was strand separated and annealed to total cell mRNA before $S_{1}$ digestion and electrophoretic resolution, which were carried out as described previously ${ }^{23,24}$. The 40 bp fragment protected by correctly initiated $\gamma 26$ mRNA is as predicted by primer extension analysis ${ }^{44}$. The solid blocks indicate the leader $(L)$ exon and $5^{\prime}$ end of the $V-D-J$ exons. $b$ Shows the derivatives of pSV. $2 \mathrm{~b} \Delta \mathrm{X}_{2}$ used for transfection. The $2.2 \mathrm{~kb} \mathrm{XbaI}$ fragment into the $X_{1}$ (M1 and M2) or $X_{2 / 4}$ (M3) sites $^{2}$ in the indicated orientations. C Shows the S1 nuclease resistant hybrids formed between the probe shown in a and: lane 1, $20 \mu \mathrm{g}$ tRNA; lane 2, $20 \mu \mathrm{g}$ RNA from J558L cells; lanes 3-7, $20 \mu \mathrm{g}$ RNA from J558L cells transfected with: lane $3, \mathrm{pSV}$. $\gamma^{2} \mathrm{bVC}^{2}$; lane 4, pSV. $\gamma 2 \mathrm{~b} \Delta \mathrm{X}_{2 / 4}$; lane 5, pSV. $\gamma 2 \mathrm{~b} \Delta \mathrm{X}_{2 / 4} \mathrm{M} 1$; lane $6, \mathrm{pSV}$. $\gamma 2 \mathrm{~b} \Delta \mathrm{X}_{2 / 4} \mathrm{M} 2$; lane 7, pSV. $r 2 \mathrm{~b} \Delta \mathrm{X}_{2 / 4}$ M3. In the two right-hand lanes are co-electrophoresed sequencing reactions ${ }^{34}$ of the probe, which allow the identification of the transcription initiation site (arrow) and the GATAA box at position -30.

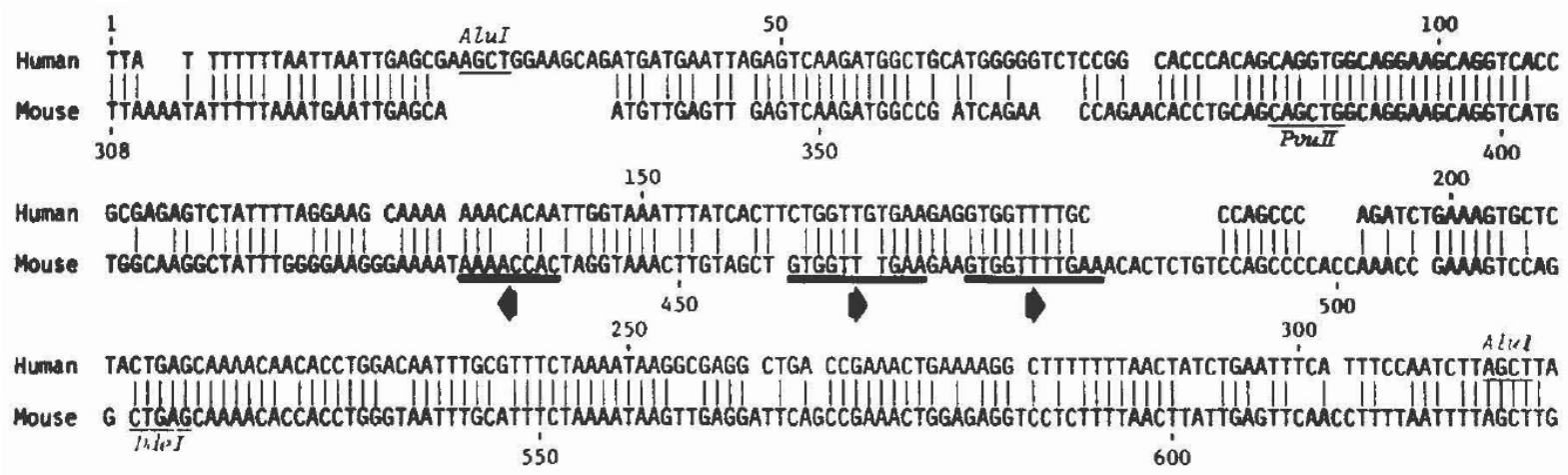

Figure 5, Sequences of the murine ${ }^{2}$ and human enhancer elements, which were compared using the SEQ computer program ${ }^{45}$. 
Figure 6, Southern blot analyses of c-myc containing sequences in J558L cells, and in their derivatives transformed with either pSV2.26 or pSV2 4 . $a$ Shows a blot obtained using probe 1 (as indicated in the diagram below) and HindIII plus EcoRI digested DNA from: lane 1, $\Delta 4.2$ cells; lane 2, $\Delta 4.1$ cells; lane 3, J558L cells; lane 4, 26.7 cells; lane 5, 26.2 cells; lane 6, 26.1 cells; lane 7, 5 pg of pSV2.26 cleaved with HindIII plus EcoRI, co-electrophoresed as a marker, $b$ Shows a blot obtained using probe 3 and BglII plus EcoRI cleaved DNA from: lane 1, 26.1 cells; lane 2, 26.5 cells; lane 3, 26.4 cells; lane 4, J558L cells; lane 5, as in lane 7 of $a$, but cut with $B g l I I$. The diagram below the blots shows the 11.7 $\mathrm{kb}$ EcoRI fragment contained in pSV2.26 and also the position of the $6.5 \mathrm{~kb}$ HindIII-EcoRI fragment. The deletion $(\Delta)$ in pSV2 $\triangle 4$ removes the HindIII site, as a result of which a $9.6 \mathrm{~kb} E c o$ RI fragment is the HindIII plus EcoRI digestion product that hybridizes to the c-myc probe. As a further result of this deletion the $3.1 \mathrm{~kb} B g l \mathrm{II}$ fragment detected with probe 3 (indicated in $b$ ) is only detected in pSV2.26 transformants. Bands labelled $\mathrm{J}$ in $a$ are due to the cross-reactivity of probe 1 with normal and rearranged mouse c-myc genes in J558L cells ${ }^{11,32}$. Restriction sites marked in the lower diagram: R, EcoRI; X, XbaI; H, HindIII; B, BglII; A, AvaI; C, ClaI.
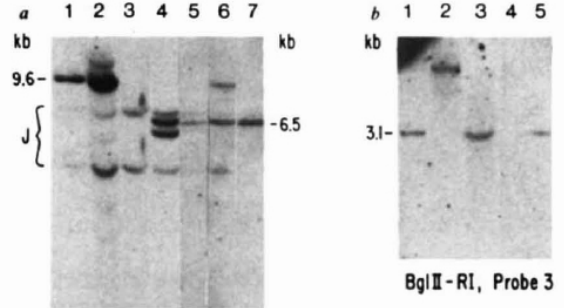

HindII-RI, Probe

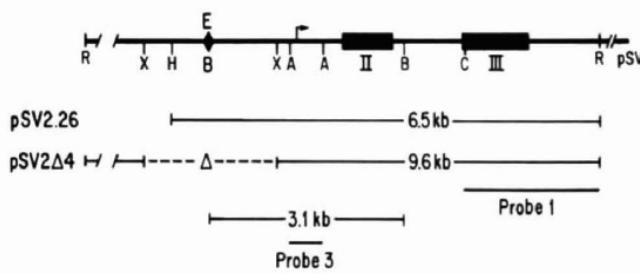

123
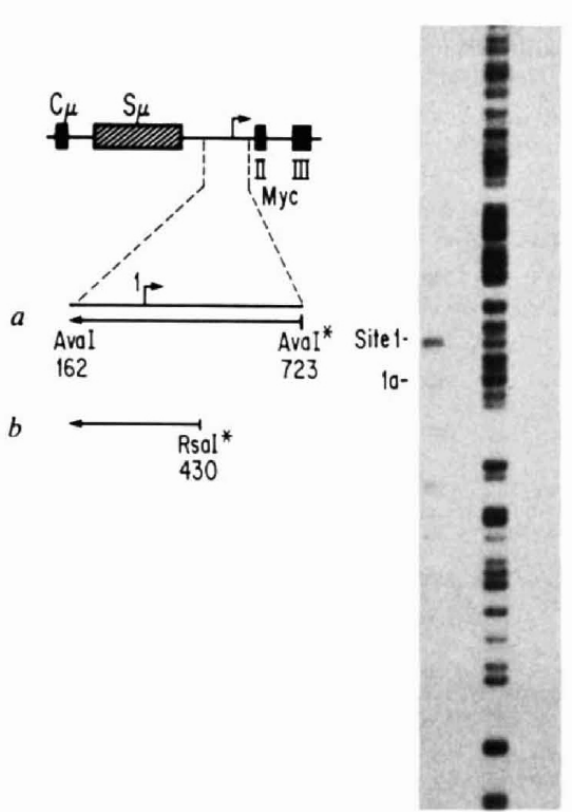

4

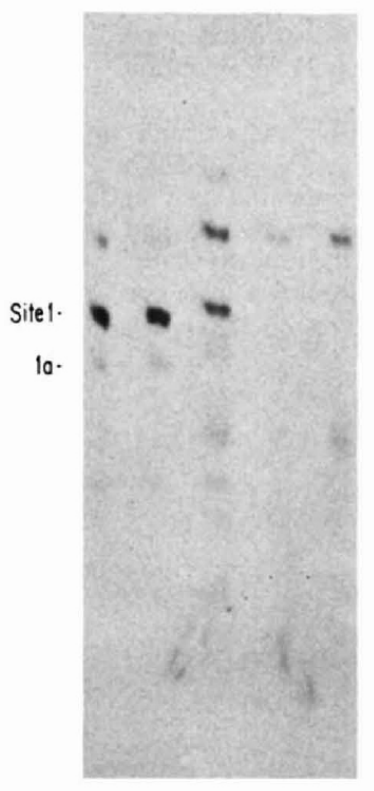

9

$11 \quad 12 \quad 13$

$3 \begin{array}{lll}34 & 15\end{array}$

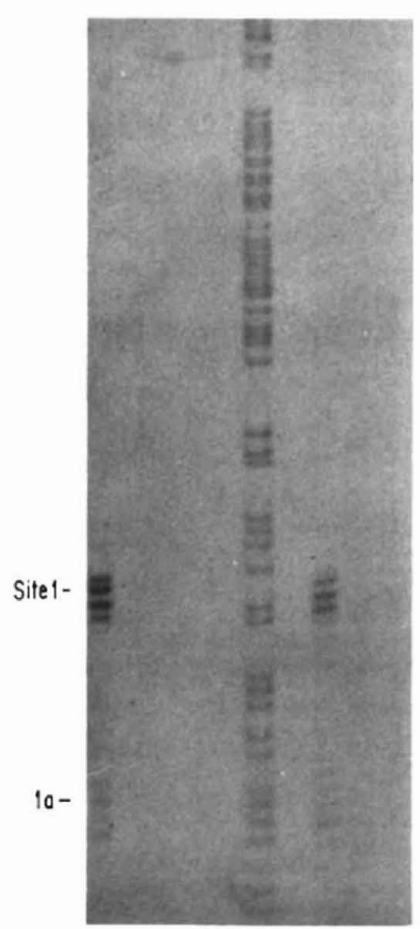

Figure 7, $\mathrm{S}_{1}$ nuclease analysis of mRNA from Manca cells, J558L cells, and transformed derivatives of J558L cells. Lanes 1-8 were reactions involving probe a, and lanes 9-15 involved probe $b$. Lane 2 is a pyrimidine sequencing reaction of probe $a$, and lane 12 is a similar reaction with probe $b$. The other lanes are the $S_{1}$ reactions, with mRNA from: lane 1, 26.7 cells; lane 3, J558L cells; lane 4, 26.1 cells; lane 5, 26.4 cells; lane 6, Manca cells; lane 7, $\Delta 4.1$ cells; lane 8, yeast cells; lane 9, Manca cells; lane 10, 26.3 cells (which retained no human c-myc sequences); lane 11, $\Delta 4.1$ cells; lane 13, 26.1 cells; lane 14, $\Delta 4.2$ cells; lane 15, J558L cells. The end-labelled, strandseparated ${ }^{41}$ probes were melted at $85^{\circ} \mathrm{C}$, then annealed to the RNAs at $51^{\circ} \mathrm{C}$ for probe a, and at $30{ }^{\circ} \mathrm{C}$ for $12 \mathrm{~h}$ for probe b. $\mathrm{S}_{1}$ digestions were carried out at $15^{\circ} \mathrm{C}$ for $2 \mathrm{~h}$. Electrophoresis was carried out as described previously, for lanes 1-8 on a $6 \%$ gel run for $7 \mathrm{~h}$, for lanes $9-15$ on an $8 \%$ gel run for $3 \mathrm{~h}$. All reactions contained equal amounts of sample RNA made up to $20 \mu \mathrm{g}$ with yeast RNA. $\mathrm{S}_{1}$ nuclease-sensitive sites specific for the presence of lymphoid RNA are indicated. 
tance upstream of a promoter are characteristic of enhancer mutations $^{33}$. As the enhancing activity of the deleted fragment has been demonstrated and largely localized to one fragment (the Alu 'a' fragment), it appears likely that it is the removal of the immunoglobulin heavy-chain locus enhancer that has drastically reduced transcription of the translocated c-myc gene.

\section{Multiple mechanisms of c-myc activation}

We show here that Manca cells contain a translocated c-myc gene that is transcribed from previously cryptic start sites that ordinarily form part of intron I of the c-myc gene. This transcription is reproduced with fidelity after introduction of the gene into mouse mycloma cells. Use of this system has allowed us to demonstrate that transcription from at least the major cryptic promoter is dramatically dependent on the presence of sequences over $350 \mathrm{bp}$ upstream of the RNA initiation site. These sequences include an element that we demonstrate to be a human immunoglobulin gene-associated enhancer element, and it may be this element itself that is responsible for activating translocated c-myc transcription in Manca cells. The remaining possibility, that it was the removal of other sequences (including about $300 \mathrm{bp}$ of DNA that are also ordinarily part of c-myc intron I) that drastically reduced transcription from initiation site I is presently being investigated. The unrearranged c-myc gene is still present in Manca cells, but our preliminary results from use of Northern probes (probe 2 in Figure 1), $S_{1}$ mapping and cDNA cloning indicate that this allele is barely, if at all, expressed. Such a situation has already been reported for a mouse plasmacytoma and may be true for other Burkitt's lymphomas ${ }^{11,32,34}$. Hence, transcriptional activation of the cmyc gene appears to be an important result of translocation and in the case described here, it is possible that such activation is largely contributed to by the immunoglobulin heavychain locus enhancer.

The retention of the immunoglobulin associated enhancer element adjacent to the translocated c-myc gene is not a common feature of c-myc translocations so far documented in either mouse $\mathrm{e}^{7,10,11,35}$ or man ${ }^{12,36}$. In these instances, the translocated gene is still transcribed $^{7,10,11,37}$, whilst again the untranslocated gene may be silent ${ }^{11,32,34}$. In these cases, transcription of the translocated c-myc gene may be maintained by a cellular enhancer-type element yet to be identified,

Received October 17; accepted November 30, 1983.

1. Tonegawa, S. Nature 302, 575-581 (1983).

2. Gillies. S.D., Morrison. S.L., Oi, V.T. \& Tonegawa, S. Cell 33, 718-728 (1983).

3. Banerii, J., Olson, L. \& Schaffner, W. Cell 33, 729-740 (1983).

4. Neuberger. M. EMBO J. 2, 1,373-1,379 (1983).

5. Hayward, W.S., Neel. B. \& Astrin, S. Nature 290, 475-480 (1981).

6. Payne, G.S., Bishop J.M. \& Varmus, H.E. Nature 295, 209-215 (1982).

7. Shen-Ong, G.L., Keath, E., Piccoli, S.P. \& Cole, M.D. Cell 31, 443-452 (1982).

8. Dalla-Favera, R., Marinotti, S., Gallo, R., Erikson. J. \& Croce, C.M. Science 219, 963-967 (1983).

9. Crews, S., Barth. R., Hood, L., Prehn, J. \& Calame. K. Science 218, 1,3191,321 (1982).

10. Marcu, K.H. et al. Proc. Natn. Acad. Sci. U.S.A. 80, 519-523 (1983).

11. Adams, J.M., Gerondakis, S., Webb. E., Corcoran, L.M. \& Cory, S. Proc. Natn: Acad. Sci. U.S.A. 80, 1,982-1,986 (1983).

12. Taub, R. et al. Proc. Natn. Acad. Sci. U.S.A. 79, 7,837-7,841 (1982).

13. Cairns. J. Nature 289, 353-357 (1981).

14. Klein, G. Nature 294, 313-318 (1981).

15. Rowley. J.D. Science 216, 749-751 (1982).

16. Nishikori, M. et al. Cancer Genet. Cytogenet. (in press).

17. Lautenberger, J.A., Schulz. R.A., Garon, C.F., Tsichlis, P.N. \& Papas, T. Proc. Natn. Acad. Sci. U.S.A. 78, 1,518-1,522 (1981).

18. Neel, B., Jhanwar, S., Chaganti, R. \& Hayward, W.S. Proc. Natn. Acad. Sci. U.S.A. $14,7,842-7,846$ (1982)

19. Grosveld, F. et al. Nucleic Acids Res. 10, 6,715-6,732 (1982).

20. Erikson. J., Finan, J., Nowell, P.C. \& Croce, C.M. Proc. Natn. Acad. Sci. U.S.A. 79, 5,611-5,615 (1982).

21. Southern, E.J. Molec. Biol. 98, 503-515 (1975).

22. Saito, H., Hayday, A.C., Wiman, K., Hayward, W.S. \& Tonegawa, S. Proc. Natn. Acad. Sci. U.S.A. 80 (in press). and which may be a considerable distance from the translocated c-myc gene.

Alternatively, translocated c-myc genes may not be directly dependent upon immunoglobulin sequences for their transcription, but rather their transcription may be activated by the accumulation of mutations in regulatory regions. For example, it has been suggested $^{34}$ that the c-myc gene product itself may regulate its own transcription, and that, in lymphomas harboring translocated genes, the translocated but not the normal c-myc gene, escapes this repression. At this stage, the hypothesis of positive activation, and that of escaping repression, are not mutually exclusive.

The detachment of c-myc exon I sequences from c-myc exons II and III is a consequence for all BALB/c and for several hutnan c-myc translocations thus far documented $\mathrm{d}^{7,10-12,38}$. We have previously suggested $^{22,31}$ that this event, in itself, leads to increased translation of c-myc RNA in cells harboring such translocations.

In summary, there are probably multiple steps in the activation of the human c-myc gene in non-Hodgkin's lymphomas. From this article it is clear that previously cryptic promoters of the c-myc gene are activated upon translocation, and that this activation is dependent upon upstream sequences. In Manca cells, the critical element in these upstream sequences may be the human immunoglobulin heavy-chain locus enhancer element. As both the translocated c-myc gene from a mouse plasmacytoma and the translocated human c-myc gene from Manca cells have detectable biological activity (reference 46 and our unpublished data) it is apparent that the activation of the c-myc gene contributes to either initiation or maintenance of oncogenesis. It is possible that the misuse of a developmentally regulated, cellular enhancer element will be found, in many cases, to be responsible for activating oncogenes.

We thank Lena Angman, John McMaster, Anne Maxwell and Eleanor Basel for their help, and P. Jat for advice concerning $\mathrm{S}_{1}$ analysis, C. M. Croce for the gift of pH18-cl-10, W. Topp for the kind distribution of rat- 2 cells, and B. Clarkson for Manca cells. A.C.H. and K.W. thank ICRF and EMBO respectively for travel and long term fellowships. The work was supported by NIH grants AI-17879 (to S.T.), CA-14051 (a core grant to S. Luria), and CA-34502 (W.H.).

Note added in proof: The integrity of all RNA preparations has been confirmed by succcessful $S_{1}$ analysis of gpt transcription.

23. Berk, A. \& Sharp, P.A. Cell 12, 721-732 (1977).

24. Weaver, R.F. \& Weissman. C. Nucleic Acids Res. 7, 1,175-1,193 (1979).

25. Colby, W.W., Chen, E.Y., Smith, D.H. \& Levinson, A.D. Nature 301, 722725 (1983).

26. Goldberg, M. thesis, Stanford Univ. (1980).

27. Breathnach, R. \& Chambon, P.A. Rev. Biochem. 50, 349-384 (1981).

28. Proudfoot, N. \& Brownlee, G. Nature 263,211-214 (1976).

29. Mulligan, R.C. \& Berg, P. Science 209, 1,422-1,427 (1980).

30. Weiher, H., Konig, M. \& Gruss, P. Science 219, 626-631 (1983).

31. Heyday, A.C. et al. Cold Spring Harb. Symp. Quant. Biol. (in press).

32. Stanton, L.W., Watt. R. \& Mareu, K.M. Nature 303, 401-406 (1983).

33. Benoist, C. \& Charbon, P. Nature 290, 304-309 (1981).

34. Nishikura, K. et al. Proc. Natn. Acad. Sci. U.S.A. 80, 4,822-4,862 (1983).

35. Calame, K., Kim, S., Laney, P., Hill, R., Davis, M. \& Hood, L. Proc. Natn. Acad. Sci. U.S.A. 79, 6,994-6,998 (1982).

36. Neuberger, M. \& Calabi, F. Nature 305, 240-243 (1983).

37. Erikson, J., ar-Rushdi, A., Drwinga, H.L., Nowell, P.C. \& Croce, C.M. Proc. Natn. Acad. Sci. U.S.A. 80, 820-824 (1983).

38. Cory, S. et al. EMBO J. 2, 213-216 (1983).

39. Sandri-Goldin. R.M., Goldin, A.L., Levine, M. \& Glorioso, J.C. Molec. Cell. Biol. 743-752 (1981).

40. Ravetch, J.V., Siebenlist, U., Korsmeyer, S., Waldmann, T. \& Leder, P. Cell 27, 583-591 (1981).

41. Maxam, A. \& Gilbert, S. Meth. Enzym. 65, 499-560 (1980).

42. Thomas, P. Proc. Natn. Acad. Sci. U.S.A. 77, 5,201-5,205 (1980).

43. Ghosh, P.K., Reddy, V.B., Swinscoe, J., Lebowitz, P. \& Weissman, S.M. J. Molec. Biol. 126, 813-846 (1978).

44. Gillies, S.D. \& Tonegawa, S. Nucleic Acids Res. 11, 7,981-7,997 (1983).

45. Brutlag, D.L., Clayton, J., Friedland, P. \& Kedes, L. Nucleic Acids Res. 10, 279-294 (1982).

46. Land, H., Parada, L.F. \& Weinberg, R.A. Nature 304, 576-580 (1983). 